\title{
Optimization of protein fractionation by skim milk microfiltration: Choice of ceramic membrane pore size and filtration temperature
}

\author{
Camilla Elise Jørgensen, ${ }^{*} \dagger^{1}$ Roger K. Abrahamsen, $\dagger$ Elling-Olav Rukke, $\dagger$ Anne-Grethe Johansen, ${ }^{*} \dagger$ \\ Reidar B. Schüller,† and Siv B. Skeie† \\ ${ }^{*}$ TINE SA, Centre for Research and Development, N-0902 Oslo, Norway \\ †Department of Chemistry, Biotechnology and Food Science, Norwegian University of Life Sciences, N-1432 Ås, Norway
}

\begin{abstract}
The objective of this study was to investigate how ceramic membrane pore size and filtration temperature influence the protein fractionation of skim milk by cross flow microfiltration (MF). Microfiltration was performed at a uniform transmembrane pressure with constant permeate flux to a volume concentration factor of 2.5. Three different membrane pore sizes, $0.05,0.10$, and $0.20 \mu \mathrm{m}$, were used at a filtration temperature of $50^{\circ} \mathrm{C}$. Furthermore, at pore size $0.10 \mu \mathrm{m}, 2$ different filtration temperatures were investigated: 50 and $60^{\circ} \mathrm{C}$. The transmission of proteins increased with increasing pore size, giving the permeate from MF with the $0.20-\mu \mathrm{m}$ membrane a significantly higher concentration of native whey proteins compared with the permeates from the $0.05-$ and $0.10-\mu \mathrm{m}$ membranes $(0.50,0.24$, and $0.39 \%$, respectively). Significant amounts of caseins permeated the $0.20-\mu \mathrm{m}$ membrane $(1.4 \%)$, giving a permeate with a whitish appearance and a casein distribution $\left(\alpha_{S^{-}}\right.$ $\left.\mathrm{CN}: \alpha_{\mathrm{S} 1}-\mathrm{CN}: \kappa-\mathrm{CN}: \beta-\mathrm{CN}\right)$ similar to that of skim milk. The 0.05 - and $0.10-\mu \mathrm{m}$ membranes were able to retain all caseins (only negligible amounts were detected). A permeate free from casein is beneficial in the production of native whey protein concentrates and in applications where transparency is an important functional characteristic. Microfiltration of skim milk at $50^{\circ} \mathrm{C}$ with the $0.10-\mu \mathrm{m}$ membrane resulted in a permeate containing significantly more native whey proteins than the permeate from $\mathrm{MF}$ at $60^{\circ} \mathrm{C}$. The more rapid increase in transmembrane pressure and the significantly lower concentration of caseins in the retentate at $60^{\circ} \mathrm{C}$ indicated that a higher concentration of caseins deposited on the membrane, and consequently reduced the native whey protein transmission. Optimal protein fractionation of skim milk into a casein-rich retentate and a permeate with native whey proteins were obtained by $0.10-\mu \mathrm{m} \mathrm{MF}$ at $50^{\circ} \mathrm{C}$.
\end{abstract}

Received February 26, 2016.

Accepted April 29, 2016.

${ }^{1}$ Corresponding author: camilla.jorgensen@tine.no
Key words: protein fractionation, ceramic membrane pore size, filtration temperature, uniform transmembrane pressure, constant flux

\section{INTRODUCTION}

The main proteins in milk, the caseins and whey proteins, differ in their functional and nutritional characteristics, and it is of interest to the dairy industry to separate these proteins. The caseins can be used to produce cheese, and high protein beverages and fermented milks. Whey proteins derived from microfiltration (MF) of milk are commonly referred to as native whey, ideal whey, or virgin whey. Native whey, as opposed to cheese whey, is free from somatic cells, lactic acid bacteria, bacteriophages, remnants of rennet (Maubois, 2002), cheese fines, and the glycomacropeptide from $\kappa-\mathrm{CN}$ (Brans et al., 2004). The neutral taste and $\mathrm{pH}$, native protein conformation, and nutritional quality of whey proteins make native whey an excellent end product or ingredient in products addressed to infant, elderly, or sports nutrition.

Casein micelles and whey proteins can be separated by the use of MF with membranes with pore sizes in the range of 0.05 to $0.20 \mu \mathrm{m}$ (Brans et al., 2004). The MF membrane material (i.e., ceramic, polymeric) and the membrane design and system [i.e., ceramic gradient, ceramic uniform transmembrane pressure (UTP), polymeric spiral-wound] influence the efficiency of whey protein removal, but also overall costs and cleaning procedures. Ceramic membranes in a UTP system give significantly better whey protein removal than ceramic graded permeability membranes and polymeric spiral-wound membranes (Zulewska et al., 2009). Optimal separation of caseins and whey proteins is of interest to the dairy industry. Therefore, the focus of this paper is on ceramic membranes in a UTP system. The composition of retentates and permeates from MF of skim milk is also influenced by several other factors: the composition of the skim milk, the pretreatment of the skim milk (Brandsma and Rizvi, 1999; Hernández and Harte, 2009; Svanborg et al., 2014), membrane 
pore size (Punidadas and Rizvi, 1999), channel geometry (Adams et al., 2015a), filtration temperature (Van Hekken and Holsinger, 2000; Hurt et al., 2015; Seibel et al., 2015), concentration factor (Punidadas and Rizvi, 1999; Kersten, 2001), wall shear stress (Le Berre and Daufin, 1996), and fouling (Le Berre and Daufin, 1996; Gésan-Guiziou et al., 1999, 2000; Jimenez-Lopez et al., 2008; Lawrence et al., 2008; Adams et al., 2015b).

Ceramic MF of skim milk to separate caseins and whey proteins is usually carried out at temperatures ranging from 50 to $55^{\circ} \mathrm{C}$. Operating at higher filtration temperatures $\left(>50^{\circ} \mathrm{C}\right)$ gives the potential benefit of reducing microbial growth (Walstra et al., 2006) and increasing flux as reported by Kersten (2001). However, Kersten (2001) observed a flux decline at temperatures above $55^{\circ} \mathrm{C}$, explained by the precipitation of calcium phosphate. Hurt et al. (2015) reported, as opposed to Kersten (2001), that calcium phosphate precipitation did not cause membrane fouling when increasing the MF temperature from 50 to $65^{\circ} \mathrm{C}$. They observed, however, a decrease in whey protein transmission with increasing filtration temperature, partly explained by the possible denaturation of whey proteins. Thus, the possible denaturation of whey proteins may be another disadvantage of MF of skim milk at higher temperatures. Significant denaturation of $\alpha$-LA and $\beta$-LG occurs on heating milk above about $70^{\circ} \mathrm{C}$ (Anema, 2009), although conformational changes of $\beta$-LG has been reported to take place already at temperatures of $40^{\circ} \mathrm{C}$ (Qi et al., 1995, 1997). The separation of milk into cream and skim milk is usually carried out at around $57^{\circ} \mathrm{C}$ (range $55-65^{\circ} \mathrm{C}$ ). In a continuous milk treatment process with ceramic $\mathrm{MF}$ at $60^{\circ} \mathrm{C}$, the skim milk can be fed directly to the filtration process without temperature adjustment. The pumping energy and the friction forces arising from the flow of feed through the MF channels contribute to a temperature increase of the feed, and the temperature is likely to rise from 57 to $60^{\circ} \mathrm{C}$. Thus, ceramic MF at $60^{\circ} \mathrm{C}$ might be relevant for the dairy industry.

Ceramic membranes with different pore sizes are available on the market. The effect of membrane pore size on the composition of MF retentate and permeate could possibly influence the choice of membrane pore size in an industrial MF application. Optimal fractionation of caseins and whey proteins is of interest to the dairy industry due to their different functional properties. Optimization of native whey protein removal and utilization of native whey proteins in valueadded products may be a key to increase profitability of a ceramic MF process. For instance, relatively small differences in whey protein concentration in the MF permeate could have a major effect on the economic feasibility of an MF process with the goal to produce a native whey protein concentrate. Punidadas and Rizvi (1999) investigated the effect of gradient membranes with pore sizes of 0.05 and $0.20 \mu \mathrm{m}$ on the composition of retentates and permeates from MF of skim milk. They reported that a portion of casein passed through the $0.20-\mu \mathrm{m}$ membrane, whereas almost all the caseins were retained by the $0.05-\mu \mathrm{m}$ membrane at the same time that whey proteins permeated the membrane. According to Zulewska et al. (2009), the permeate from MF of skim milk with gradient membranes has a higher casein proportion compared with permeate from MF of skim milk with ceramic membranes operated at a UTP. Information concerning the effect of different pore size on the protein fractionation of skim milk in a UTP MF system seems to be lacking and should be further investigated.

Milk proteins are the most valuable constituent of milk, and quantitative determination is important. Electrophoresis and column liquid chromatography are the main techniques used to separate and quantify milk proteins (Dupont et al., 2013). Protein compositions as found with capillary electrophoresis and reversed-phase HPLC are often given as relative values (Miralles et al., 2003; Heck et al., 2008; Svanborg et al., 2014) because of the difficulties in using standard curves for quantification of protein concentrations due to the impurity of the protein standards. Important information may get lost with the interpretation of relative values. A useful procedure to calculate real protein concentration values based on capillary electrophoresis is therefore presented in the present study.

Kersten (2001) and Hurt et al. (2015) studied the effect of temperature on protein fractionation using an MF system run in recycle mode at a constant transmembrane pressure (TMP) resulting in a minimal change in flux with filtration time. Investigation of the effect of MF temperature in recycle mode cannot preclude potential effects of the recycle time on the protein fractionation. Industrially, it is common to run MF processes at flux values above the critical flux to maximize the utilization of the membrane area, although operation above the critical flux causes fouling and can reduce operating time (Gésan-Guiziou et al., 2000). In an industrial MF process, the flux is kept constant because downstream unit operations in a continuous process are depending on a constant flow.

The objective of this study was to investigate the effect of membrane pore size and filtration temperature on protein fractionation of skim milk by MF to optimize fractionation of caseins and whey proteins. Ceramic MF in a UTP system was performed with a volume concentration factor of 2.5 and with a constant permeate flux to model an industrial MF application. 


\section{MATERIALS AND METHODS}

\section{Experimental Design}

Three pore sizes, $0.05,0.10$, and $0.20 \mu \mathrm{m}$, were investigated at filtration temperature of $50^{\circ} \mathrm{C}$. At a pore size of $0.10 \mu \mathrm{m}, 2$ filtration temperatures were investigated: 50 and $60^{\circ} \mathrm{C}$. The scope of the experiments rendered it impossible to investigate the effect of all factor levels on the same milk; therefore, the experiments were performed with 7 different milk deliveries. Two MF experiments were performed on milk from each milk delivery (the day of delivery and the following day); thus, a total of $14 \mathrm{MF}$ experiments were conducted.

\section{Microfiltration Feed Preparation}

Milk was obtained from the university farm and separated (Westfalia Separator AG, MSD50-01-076, Oelde, Germany) at $63^{\circ} \mathrm{C}$ to an average fat content of $0.06 \pm$ $0.01 \%$. The skim milk was pasteurized in a plate heat exchanger (M6-MFMC, Alfa-Laval, Lund, Sweden) at $73^{\circ} \mathrm{C}$ for $15 \mathrm{~s}$ and cooled to $4^{\circ} \mathrm{C}$. The pasteurized skim milk was split into 2 parts. One part was microfiltered the same day, and one part was stored at $4^{\circ} \mathrm{C}$ and microfiltered the following day. Before MF, the skim milk was gently heated under continuously stirring to $45^{\circ} \mathrm{C}$
$\left(\Delta 4^{\circ} \mathrm{C}-45^{\circ} \mathrm{C}=27\right.$ to $\left.34 \mathrm{~min}\right)$ in a steam connected double-jacketed 300-L tank. The skim milk was kept at 42 to $45^{\circ} \mathrm{C}$ for $15 \mathrm{~min}$ to partially reverse potential $\beta-\mathrm{CN}$ leakage from the casein micelle (Rose, 1968; Liu et al., 2013) and solubilization of minerals (Schmitt et al., 1993) caused by cold storage of the milk.

\section{Microfiltration}

Microfiltration was performed on a pilot-scale MF system (Membranteknikk AS, MTCVV 3-25, Flekkefjord, Norway) equipped with a permeate pump (UTP system) and a cold permeate system according to US Patent No. 13/635,335 (NO Pat. No. 330,181; Hoffmann, 2011). The MF system is schematically presented in Figure 1 and the specifications of the ceramic membranes used are given in Table 1 . All ceramic membranes were $1.178 \mathrm{~m}$ in length and had round retentate flow channels.

Before MF of milk, the system was equilibrated with water. The centrifugal pump was adjusted to reach a crossflow velocity of $6.7 \mathrm{~m} / \mathrm{s}$ with water, leading to a target crossflow velocity of $6.9 \mathrm{~m} / \mathrm{s}$ with pasteurized skim milk (Table 1). Table 2 gives an overview of the operational values during MF of pasteurized skim milk. The MF was performed with a volume concentration

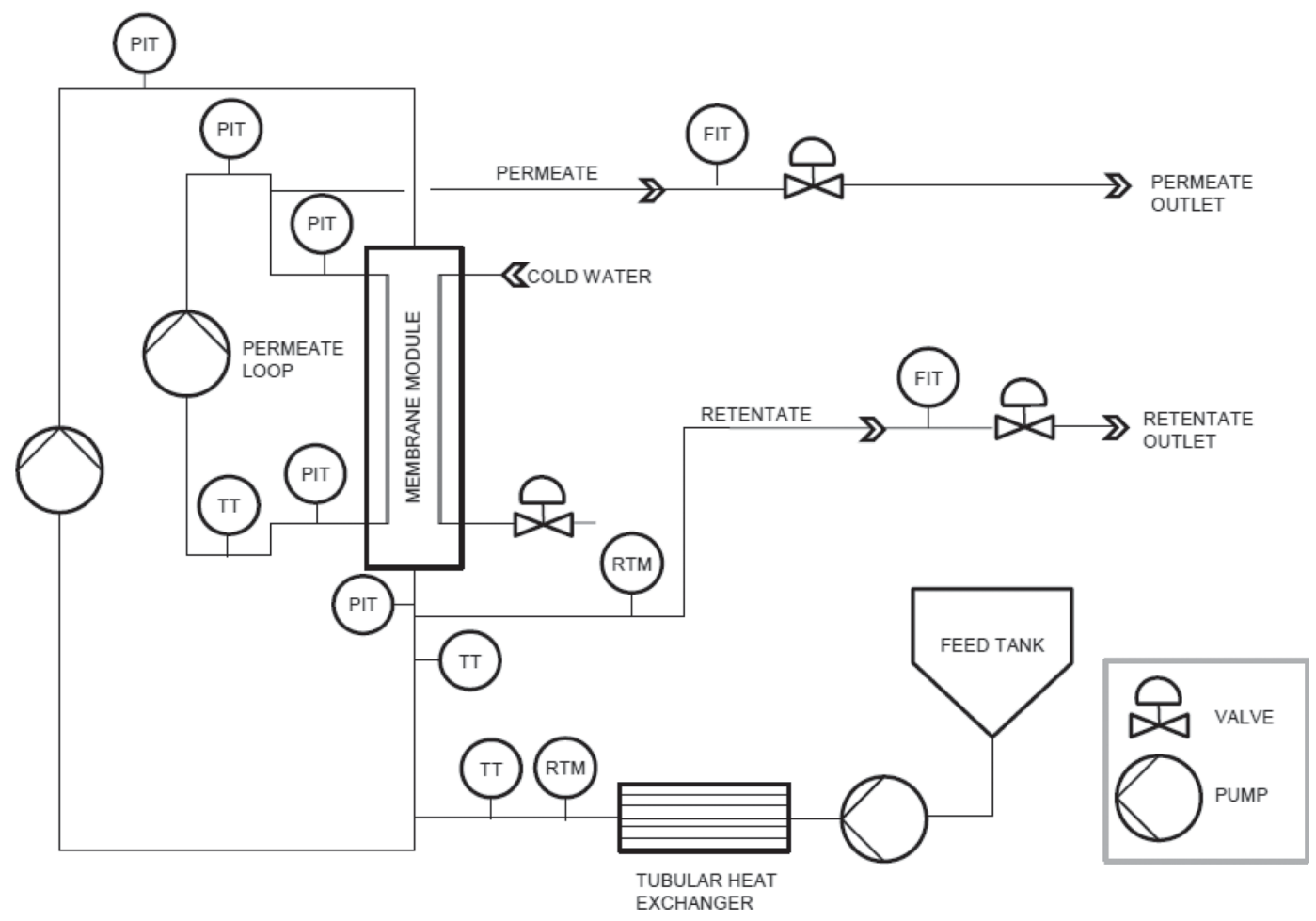

Figure 1. Schematic diagram of the microfiltration membrane system including a permeate loop with cold permeate system. FIT; flow indicator transmitter, PIT; pressure indicator transmitter, RTM; relative turbidity monitor, TT; temperature transmitter. 
Table 1. Specification of ceramic membranes used for microfiltration of pasteurized skim milk

\begin{tabular}{lccc}
\hline & \multicolumn{3}{c}{ Membrane pore size $(\mu \mathrm{m})$} \\
\cline { 2 - 4 } Item & 0.05 & 0.10 & 0.20 \\
\hline Producer $^{1}$ & Orelis & Orelis & Atech \\
Hydraulic diameter $(\mathrm{mm})$ & 2.9 & 2.9 & 3.3 \\
Number of membranes used for microfiltration & 2 & 2 & 3 \\
Membrane area/membrane $\left(\mathrm{m}^{2}\right)$ & 0.34 & 0.34 & 0.24 \\
Number of channels/membrane & 31 & 31 & 19 \\
Membrane material & $\mathrm{TiO}_{2} / \mathrm{ZrO}_{2}$ & $\mathrm{TiO}_{2} / \mathrm{ZrO}_{2}$ & $\mathrm{\alpha}_{-} \mathrm{Al}_{2} \mathrm{O}_{3} / \mathrm{TiO}_{2} / \mathrm{ZrO}_{2}$ \\
$\Delta$ Pressure (kPa) giving crossflow velocity of $6.9 \mathrm{~m} / \mathrm{s}$ & $290^{2}$ & $290^{2}$ & $260^{3}$ \\
${ }^{1}$ Orelis Environnement SAS, Salindres, France. Atech Innovations $\mathrm{GmbH}, \mathrm{Gladbeck}, \mathrm{Germany}$. \\
${ }^{2}$ Information given by producer. & & & \\
${ }^{3}$ Calculated value. & &
\end{tabular}

factor of 2.5 at constant flux. Due to the increased TMP with decreasing pore sizes, the constant flux at MF with the $0.05 \mu \mathrm{m}$ membrane was set to $44 \mathrm{~L} / \mathrm{m}^{2}$ $\mathrm{h}$ compared with a constant flux of $58.6 \mathrm{~L} / \mathrm{m}^{2} \mathrm{~h}$ for membranes with 0.10 and $0.20 \mu \mathrm{m}$ pore sizes. Minimal variation in the skim milk composition made it possible to use the same volume concentration factor in all replicate blocks.

The skim milk temperature at the inlet of the feed tank was $45^{\circ} \mathrm{C}$. The filtration temperature of the skim milk was measured at the outlet of the module and was adjusted by controlling the tubular heat exchanger and the cold permeate system (Figure 1). In addition, the pumping energy and the friction forces arising from the flow of feed through the membrane channel contributed to a temperature increase of the feed. The lower pump capacity required to obtain the set crossflow velocity during MF with the 0.20- $\mu \mathrm{m}$ membrane (larger hydraulic diameter) resulted in a lower temperature increase than for the 0.05- and 0.10- $\mu \mathrm{m}$ membranes. For this reason, the feed temperature adjusted by the tubular heat exchanger was increased to a set temperature of $50^{\circ} \mathrm{C}$ for the $0.20-\mu \mathrm{m}$ membrane (Table 2). The higher increase in temperature caused by friction in the membranes with smaller hydraulic diameters $(0.05$ and $0.10 \mu \mathrm{m})$ was adjusted by reducing the permeate temperature (Table 2). A filtration temperature of $60^{\circ} \mathrm{C}$ during MF with the $0.10-\mu \mathrm{m}$ membrane was reached by increasing both the feed temperature and the permeate temperature.

A MilkoScan FT1 (Foss, Hillerød, Denmark) with Fourier transform infrared analytical technology was

Table 2. Operational values (mean $\pm \mathrm{SD}, \mathrm{n}=3$ or 4 ) during microfiltration of pasteurized skim milk at $50^{\circ} \mathrm{C}$ with ceramic membranes with pore sizes of $0.05,0.10$, and $0.20 \mu \mathrm{m}$, and at $60^{\circ} \mathrm{C}$ with a $0.10-\mu \mathrm{m}$ membrane

\begin{tabular}{|c|c|c|c|c|}
\hline \multirow[b]{2}{*}{ Item } & \multicolumn{3}{|c|}{$\begin{array}{c}\text { Filtration } \\
\text { temperature } 50^{\circ} \mathrm{C}\end{array}$} & \multirow{2}{*}{$\begin{array}{c}\begin{array}{c}\text { Filtration } \\
\text { temperature } 60^{\circ} \mathrm{C}\end{array} \\
0.10 \mu \mathrm{m}\end{array}$} \\
\hline & $0.05 \mu \mathrm{m}$ & $0.10 \mu \mathrm{m}$ & $0.20 \mu \mathrm{m}$ & \\
\hline Pressure retentate inlet $(\mathrm{kPa})$ & $487 \pm 0$ & $487 \pm 1$ & $459 \pm 1$ & $487 \pm 1$ \\
\hline Pressure permeate inlet ( $\mathrm{kPa})$ & $398 \pm 7$ & $407 \pm 9$ & $416 \pm 0$ & $413 \pm 5$ \\
\hline Pressure retentate outlet $(\mathrm{kPa})$ & $196 \pm 0$ & $195 \pm 1$ & $196 \pm 0$ & $195 \pm 1$ \\
\hline Pressure permeate outlet (kPa) & $106 \pm 7$ & $114 \pm 8$ & $153 \pm 0$ & $120 \pm 5$ \\
\hline Mean $\mathrm{TMP}^{1}(\mathrm{kPa})$ & $89 \pm 7$ & $81 \pm 8$ & $43 \pm 1$ & $75 \pm 5$ \\
\hline$\tau_{\mathrm{w}}^{2}(\mathrm{~Pa})$ & 179 & 180 & 180 & 184 \\
\hline Feed temperature $\left({ }^{\circ} \mathrm{C}\right)$ & $44.0 \pm 0.2$ & $45.4 \pm 1.6$ & $50.3 \pm 0.3$ & $52.7 \pm 0.6$ \\
\hline Filtration temperature $\left({ }^{\circ} \mathrm{C}\right)$ & $50.1 \pm 0.1$ & $50.1 \pm 0.2$ & $50.0 \pm 0.2$ & $59.9 \pm 0.1$ \\
\hline Permeate temperature $\left({ }^{\circ} \mathrm{C}\right)$ & $44.4 \pm 0.1$ & $43.8 \pm 0.1$ & $48.6 \pm 0.3$ & $55.6 \pm 0.2$ \\
\hline Flow retentate $(\mathrm{L} / \mathrm{h})$ & $20 \pm 0$ & $27 \pm 0$ & $28 \pm 0$ & $27 \pm 0$ \\
\hline Flow permeate $(\mathrm{L} / \mathrm{h})$ & $30 \pm 0$ & $40 \pm 0$ & $42 \pm 0$ & $40 \pm 0$ \\
\hline Flux $\left(\mathrm{L} / \mathrm{m}^{2} \mathrm{~h}\right)$ & $44.1 \pm 0.0$ & $58.9 \pm 0.1$ & $58.3 \pm 0.0$ & $58.9 \pm 0.1$ \\
\hline Volume concentration factor ${ }^{3}$ & $2.5 \pm 0.0$ & $2.5 \pm 0.1$ & $2.5 \pm 0.0$ & $2.5 \pm 0.1$ \\
\hline
\end{tabular}

${ }^{1} \mathrm{TMP}=$ transmembrane pressure $=\left\{\left[\left(\mathrm{Rp}_{\mathrm{i}}-\mathrm{Pp}_{\mathrm{i}}\right)+\left(\mathrm{Rp}_{\mathrm{o}}-\mathrm{Pp}_{\mathrm{o}}\right)\right] / 2\right\}$, where $\mathrm{Rp_{i }}=$ retentate pressure inlet, $R p_{o}=$ retentate pressure outlet, $\mathrm{Pp}_{\mathrm{i}}=$ permeate pressure inlet, $\mathrm{Pp}_{\mathrm{o}}=$ permeate pressure outlet.

${ }^{2} \tau_{\mathrm{w}}=$ wall shear stress $=\left\{\Delta \mathrm{P} \times\left[\mathrm{d}_{\text {hydraulic }} /(4 \times \mathrm{L})\right]\right\}$, where $\Delta \mathrm{P}=\left(\mathrm{Rp}_{\mathrm{i}}-\mathrm{Rp}_{\mathrm{o}}\right), \mathrm{d}_{\text {hydraulic }}$ is the hydraulic diameter, $\mathrm{L}$ is the membrane length.

${ }^{3}$ Volume concentration factor $=[($ flow retentate + flow permeate $) /$ flow retentate $]$. 
used to measure the macro composition of skim milk, retentates, and permeates during MF. When a protein content of $7.35 \pm 0.05 \%$ in the retentate from MF at pore size 0.05 and $0.10 \mu \mathrm{m}$ was reached, the collection of retentate and permeate in separate cooling tanks started (time 0). The accumulation of retentate and permeate continued for $100 \mathrm{~min}$. The time from the pasteurized skim milk was fed into the system and until the collection of fractions started was 90 to 95 min for the $0.10-\mu \mathrm{m}$ membrane, and $120 \mathrm{~min}$ for the $0.05-\mu \mathrm{m}$ membrane. Due to loss of proteins to the permeate during $\mathrm{MF}$ at $0.20 \mu \mathrm{m}$, the protein content of the retentate did not reach the target value of $7.35 \pm 0.05 \%$ at the given volume concentration factor. Therefore, the collection of retentate and permeate from MF at $0.20 \mu \mathrm{m}$ started at a protein concentration of the retentate of $5.95 \pm 0.05 \%$ (after $120 \mathrm{~min}$ ). During MF, samples of retentate and permeate were directly sampled from the outlet every 15th min and measured by MilkoScan FT1. Representative samples for chemical and physical analyses were sampled from the tanks containing accumulated retentate and permeate, respectively.

\section{Cleaning Procedure}

After displacing milk by water, the system was cleaned with $3.5 \%$ (vol/vol) alkaline detergent (Ultrasil 25, Ecolab Deutschland GmbH, Monheim am Rhein, Germany) at $80^{\circ} \mathrm{C}$ for 20 min followed by a permeate flush for $3 \mathrm{~min}$. The alkaline cleaning procedure was repeated with $1.5 \%$ (vol/vol) alkaline detergent at $80^{\circ} \mathrm{C}$ for $20 \mathrm{~min}$ followed by a permeate flush for $6 \mathrm{~min}$. The system was finally cleaned with $1.5 \%$ (vol/vol) acidic detergent (nitric acid 65\%, VWR International, Fontenay-sous-Bois, France) at $50^{\circ} \mathrm{C}$ for 20 min followed by a permeate flush for $6 \mathrm{~min}$. Before every MF run, the system was conditioned with $1.5 \%$ (vol/vol) alkaline detergent at $80^{\circ} \mathrm{C}$ for $20 \mathrm{~min}$, followed by a permeate flush for $6 \mathrm{~min}$. The system was always thoroughly rinsed with water before feeding the system with milk.

\section{Chemical Analyses}

Samples for chemical analyses were freshly frozen and thawed the day of analysis. The content of total solids was determined according to oven drying at $102 \pm 2^{\circ} \mathrm{C}$ for $24 \mathrm{~h}$ (IDF, 2010a). Fat content was determined according to the Röse Gottlieb method (IDF, 2010b). Minerals (Ca, P, K, Na, Mg, Cu) were quantified by the method described by Jørgensen et al. (2015). For quantification of minerals, ERM-BD150 and ERM-BD151 (Institute for Reference Materials and Measurements, Geel, Belgium) were used as reference materials. To- tal nitrogen (TN), CP, NPN, and noncasein nitrogen (NCN) were determined using the Kjeldahl method [IDF, 2014 (TN and CP), IDF, 2001, and IDF, 2004, respectively]. True protein (TP) was calculated by subtracting NPN from TN. Casein was calculated by subtracting NCN from TN. Native whey protein (NWP) was calculated by subtracting NPN from NCN. A multiplying factor of 6.38 was used to calculate the amount of the various protein components. Lactose was quantified by HPLC as described by Moe et al. (2013). The $\mathrm{pH}$ was measured with a $\mathrm{pH}$ meter equipped with a temperature probe (Radiometer Copenhagen, Nerliens Kemisk Tekniske AS, Oslo, Norway).

Transmission of Proteins. Transmission rate of proteins (T) as measured with MilkoScan FT1 was calculated by using the relation $\mathrm{T}(\%)=(\mathrm{Cp} / \mathrm{Cr}) \times$ 100 , where $\mathrm{Cp}$ and $\mathrm{Cr}$ are the protein concentration in permeate and retentate, respectively (Morin et al., 2004).

Capillary Electrophoresis. Run buffer ( $\mathrm{pH} 3.0$ \pm 0.1 ) was made according to Heck et al. (2008) and filtered through a $0.20-\mu \mathrm{m}$ filter (no. 83.1826.001, Sarstedt, Nümbrecht, Germany). Sample buffer (pH 8.6 \pm 0.1 ) was prepared according to Recio et al. (1997). Sample buffer $(900 \mu \mathrm{L})$ and milk sample $(600 \mu \mathrm{L})$ were mixed, vortexed, and left on a benchtop shaker for 1 $\mathrm{h}$ at room temperature and finally filtered through a 0.45- $\mu \mathrm{m}$ filter (no. 28145-503, VWR, Radnor, PA). Analysis of samples was performed on an Agilent capillary electrophoresis system (model G1600AX) controlled by an Agilent 3D-CE ChemStation software (Agilent Technologies Deutschland GmbH \& Co. KG, Waldbronn, Germany). Separations were performed using a fused-silica capillary with an internal diameter of $50 \mu \mathrm{m}$ and a length of $56 \mathrm{~cm}$ (no. G1600-61211) and a 50- $\mu \mathrm{m}$ alignment interface (no. G1600-60210). Separations were carried out at $45^{\circ} \mathrm{C}$ with a linear gradient voltage from 0 to $25 \mathrm{kV}$ for $3 \mathrm{~min}$, followed by a constant voltage of $25 \mathrm{kV}$ for 40 min. Before each run, the capillary was flushed with $0.1 \mathrm{M} \mathrm{NaOH}$ for 5 min, and subsequently flushed and conditioned with run buffer for 20 min. Each sequence comprised 12 injections interrupted by a flush with run buffer before every injection. Skim milk and retentate samples were injected at a pressure of $3.45 \mathrm{kPa}$ for $20 \mathrm{~s}$. Due to lower concentrations of proteins in permeates, the injection duration of permeates was increased to $60 \mathrm{~s}$ to intensify the absorbance. Proteins were detected by a UV detector at $214 \mathrm{~nm}$. Each sample was prepared twice and each sample preparation was distributed on 3 vials to obtain a total of 6 measurements of each sample. Electropherograms were integrated with a valley-to-valley approach (Miralles et al., 2003). Peaks were identified 
according to Heck et al. (2008); however, the identification of $\alpha_{\mathrm{S}_{1}} \mathrm{CN}$ was based on the fact that this protein only has 2 phosphorylation states (Farrell et al., 2004). Figure 2 shows the identification of peaks in electropherograms of skim milk, retentate from MF with the $0.05-\mu \mathrm{m}$ membrane, and permeates from MF with the 0.05 - and $0.20-\mu \mathrm{m}$ membranes. Electropherograms of retentates from MF with different membrane pore sizes were similar, and electropherograms of permeates from MF with $0.05-$ and $0.10-\mu \mathrm{m}$ membranes were similar. The peak identification was verified by comparing the electropherograms of the samples with electropherograms of a milk sample or a permeate sample added standards of caseins and whey proteins (Sigma-Aldrich, St. Louis, MO). The relative concentration (\%) of proteins in a sample was calculated by dividing the peak area by total peak area and adjusting for migration time (Heck et al., 2008).

The quantification of proteins based on capillary electrophoresis results could be performed with standard curves of each protein. However, the impurity of protein standards makes this difficult and could potentially result in over- or underestimation of the protein concentration. A new calculation procedure that eliminates the need for standard curves is therefore presented. The protein composition (\%) of a sample was calculated by adjusting the relative concentration of a protein (1) with the TP content (Kjeldahl method) of that particular sample, and (2) with the molar extinction coefficient of that particular protein. Molar extinction coefficients $(1 / M \mathrm{~cm})$ of proteins were calculated according to Kuipers and Gruppen (2007): $\alpha$-LA $=300,395 ; \beta-\mathrm{LG}=293,362 ; \alpha_{\mathrm{S}_{2}} \mathrm{CN}=401,482 ; \alpha_{\mathrm{S} 1}-\mathrm{CN}$ $=421,781 ; \kappa-\mathrm{CN}=332,759 ;$ and $\beta-\mathrm{CN}=423,992$. The new calculation procedure overestimates the content of $\alpha-\mathrm{LA}$ and $\beta-\mathrm{LG}$ as it does not include other serum proteins (e.g., lactoferrin, immunoglobulins, BSA). However, in further use of this procedure, the full spectrum of serum proteins can be included.

\section{Physical Analyses}

Viscosity was measured on fresh samples using a rheometer type MCR 301 with a bob $(\mathrm{CC} 27 / \mathrm{Ti})$ and cup (CC27/T200/Ti) geometry (Anton Paar GmbH, Graz, Austria). The cup was tempered to the filtration temperature $\left(50\right.$ or $\left.60^{\circ} \mathrm{C}\right)$ used during production of the sample. Sample $\left(4^{\circ} \mathrm{C}\right)$ was added to the cup and the measurement started when the temperature had been sufficiently stabilized. The spindle rotated at a constant shear rate of $100 \mathrm{l} / \mathrm{s}$ for $500 \mathrm{~s}$ with 100 measurement points. During the first period of the measurement, the viscosity of the samples decreased as a function of time. Further investigations revealed that the steady-state

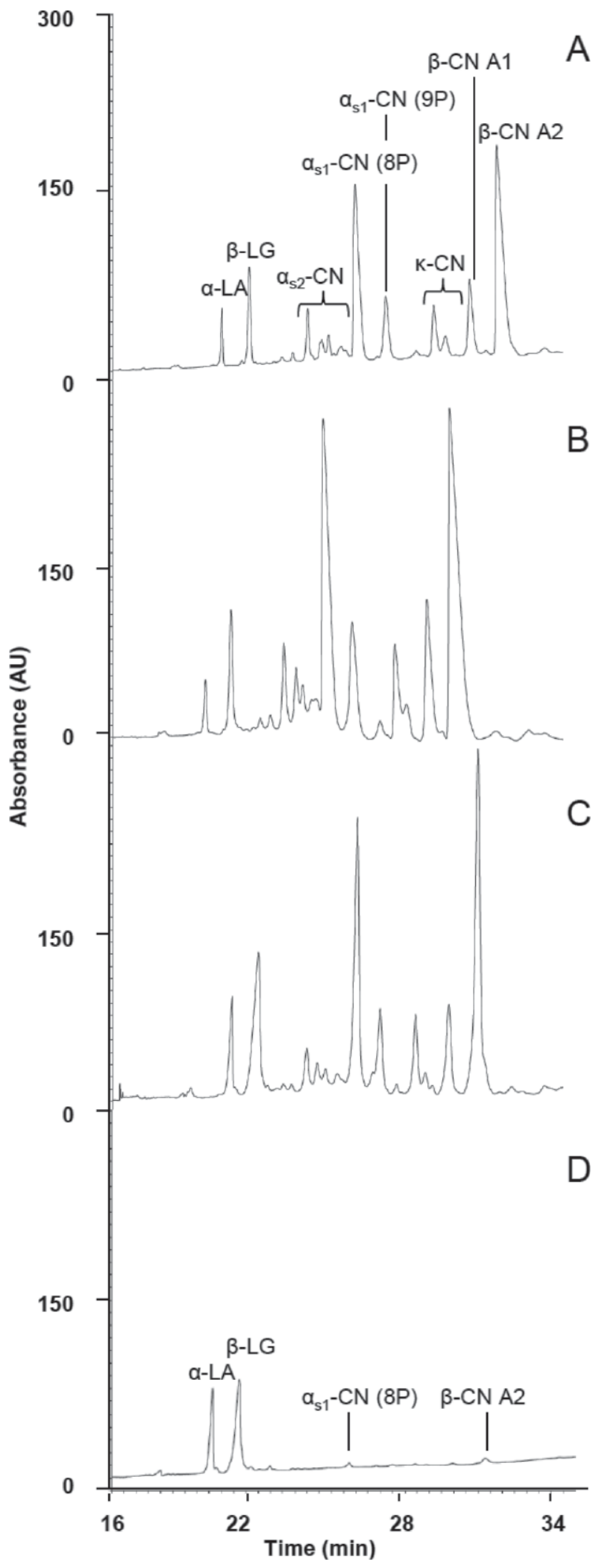

Figure 2. Electropherograms of (A) pasteurized skim milk, (B) retentate from microfiltration with a $0.05-\mu \mathrm{m}$ membrane, $(\mathrm{C})$ permeate from microfiltration with a $0.20-\mu \mathrm{m}$ membrane, and (D) permeate from microfiltration with a $0.05-\mu \mathrm{m}$ membrane. 
temperature of the system was reached after about 300 to $500 \mathrm{~s}$ of measurement (results not shown). With the use of Matlab (The MathWorks Inc., Natick, MA) the asymptotic viscosity value, which means the viscosity at infinite time, was predicted according to the least square method (Schüller et al., 2010). The asymptotic value represents the viscosity of the sample at the given final steady-state filtration temperature.

Particle size distribution of fresh samples from MF at $0.20 \mu \mathrm{m}$ was determined by dynamic light scattering. Measurements were performed using a Zetasizer $3000 \mathrm{HS}$ particle size analyzer equipped with a $633 \mathrm{~nm}$ laser (Malvern Instruments Ltd., Malvern, UK). Milk samples were mixed with filtered $(0.22 \mu \mathrm{m})$ simulated milk ultrafiltrate (Jenness and Koops, 1962) in the ratio 1:240. The mixture with simulated milk ultrafiltrate and sample was filtered $(0.8 \mu \mathrm{m})$ into a plastic cuvette and measured at a scattering angle of $90^{\circ}$ at $25^{\circ} \mathrm{C}$. The particle size distribution represented the casein micelle size distribution because the sample was mainly composed of caseins.

\section{Statistical Treatment}

For statistical treatment of data the $\mathrm{R}$ version 3.0.1 (The R Project for Statistical Computing; https:// www.r-project.org/) was applied. First, it was investigated whether the random factors, replicate block and production day, significantly influenced any selected responses (CP, TP, CN, and NWP). Replicate block corresponds to the day of milk delivery $(7$ milk deliveries), and production day corresponds to the day of filtration (MF the day of milk delivery or the following day). It was only possible to check the potential significance of replicate block on responses from experiments with 0.05 - and $0.20-\mu \mathrm{m}$ membranes, because experiments with these pore sizes both were run on the same milk deliveries (same replicate blocks). Data from these experiments were fitted to a linear ANOVA model with pore size as a fixed factor and replicate block and production day as random factors. Replicate block had no significant effect on the selected responses. Further statistical analysis was therefore done by fitting data to an ANOVA model with pore size or filtration temperature as a fixed factor and production day as a random factor. Tukey's studentized range test was applied to confirm significant differences $(P<0.05)$ between sample means. Paired t-test (Minitab 17, Minitab Ltd., Coventry, UK) was applied to determine whether a statistically significant difference was obtained between the protein adjusted protein concentration and the protein and absorbance adjusted protein concentration based on capillary electrophoresis results.

\section{RESULTS}

\section{Effect of Pore Size on Composition of Retentates and Permeates}

The chemical composition and physical characteristics of retentates and permeates from MF of skim milk with different pore sizes at filtration temperature $50^{\circ} \mathrm{C}$ are presented in Table 3 . The significantly lower concentration of TS in the retentate from MF with the $0.20-\mu \mathrm{m}$ membrane than in the retentates from MF with the $0.05-$ and $0.10-\mu \mathrm{m}$ membranes revealed that additional components permeated the $0.20-\mu \mathrm{m}$ membrane. The significantly lower TS content in the retentate was due to the significantly lower concentration of protein (CP and TP), as no significant differences were found in fat and lactose content between the retentates from MF with different pore sizes. The permeate from MF with the $0.20-\mu \mathrm{m}$ membrane had a significantly higher concentration of proteins (CP, TP, CN, and NWP) and a higher $\mathrm{pH}$ compared with the permeates from $\mathrm{MF}$ with smaller pore sizes. Kjeldahl analysis showed that caseins permeated through the $0.20-\mu \mathrm{m}$ membrane, causing an opaque whitish appearance. The casein micelle size distribution in the permeate was significantly smaller than in the retentate. The absence of casein micelles in permeates from MF with $0.05-$ and $0.10-\mu \mathrm{m}$ membranes gave these permeates translucent yellowish appearances.

The content of $\mathrm{TP}$ in retentates from MF with the 0.05 - and $0.10-\mu \mathrm{m}$ membranes did not differ; however, the membrane with $0.05-\mu \mathrm{m}$ pore size retained significantly more native whey proteins than the 0.10$\mu \mathrm{m}$ membrane. The significantly lower content of native whey proteins in the permeate from the $0.05-\mu \mathrm{m}$ membrane supported this observation. As expected, the levels of calcium and phosphorus in retentates and permeates tended to follow the casein content, due to the presence of these minerals in the casein micelles. Significantly higher concentrations of calcium and phosphorus were detected in the permeate when using the $0.20-\mu \mathrm{m}$ membrane. Also significantly more magnesium and copper passed through the $0.20-\mu \mathrm{m}$ membrane compared with the membranes with the smaller pores. The retentate from MF with the $0.05-\mu \mathrm{m}$ membrane contained significantly more copper than the retentate from MF with the $0.10-\mu \mathrm{m}$ membrane.

Capillary electrophoresis was used to separate and quantify proteins. Table 4 gives an overview of the different calculations used to calculate the protein compositions based on the results from capillary electrophoresis of skim milk, retentate, and permeate from MF with the $0.10-\mu \mathrm{m}$ membrane at $50^{\circ} \mathrm{C}$. The protein composition as found with capillary electrophoresis 
IMPORTANT FACTORS FOR PROTEIN FRACTIONATION

was reported as a relative concentration by dividing peak area by total peak area, as shown in the first subcolumn of each sample type. However, if the TP content of the sample is known, the relative concentration can be protein adjusted to find the real protein composition and concentration of the sample, as shown in the second subcolumn of each sample type. Based on the fact that proteins in milk absorb UV light at $214 \mathrm{~nm}$ to a varying extent, the protein content can be adjusted with the molar extinction coefficient of the respective protein, as shown in the third subcolumn of each sample type. By adjusting the protein content for both TP content and molar extinction coefficient, the protein concentration in pasteurized skim milk and retentate differed significantly compared with the values obtained by only adjusting for TP content.

Figure 3 shows the protein composition of pasteurized skim milk and retentates and permeates from MF of pasteurized skim milk using membranes with different pore sizes. The protein composition is adjusted for both TP content in the respective sample and molar extinction coefficient of the specific protein. A significantly higher amount of $\beta-\mathrm{LG}, \alpha_{\mathrm{S2}^{-}} \mathrm{CN}, \alpha_{\mathrm{S}_{1}} \mathrm{CN}, \kappa-\mathrm{CN}$, and $\beta-\mathrm{CN}$ were retained with the 0.05 and $0.10 \mu \mathrm{m}$ membranes than with the $0.20-\mu \mathrm{m}$ membrane, supporting the findings based on the Kjeldahl analysis. The retentate from MF of skim milk with the $0.10-\mu \mathrm{m}$ membrane contained significantly less $\alpha$-LA and $\beta$-LG and significantly more $\alpha_{\mathrm{S1}^{-}} \mathrm{CN}$ than the retentate from MF of skim milk with pore size of $0.05 \mu \mathrm{m}$. The lower retention of $\alpha$-LA and $\beta$-LG with the $0.10-\mu \mathrm{m}$ membrane resulted in a permeate with a significantly higher concentration of these whey proteins. The casein distribution $\left(\alpha_{\mathrm{S}_{2}} \mathrm{CN}\right.$ : $\alpha_{\mathrm{S}_{1}} \mathrm{CN}: \kappa-\mathrm{CN}$ : $\left.\beta-\mathrm{CN}\right)$ of the permeate from MF with membrane pore size of $0.20 \mu \mathrm{m}$ (10: 38: 10: 42) was almost similar to that of pasteurized skim milk (13: 37: 8: 42), whereas negligible amounts of caseins were found in permeates from MF with 0.05 - and $0.10-\mu \mathrm{m}$ membranes.

\section{Effect of Filtration Temperature on Composition of Retentates and Permeates}

The chemical composition and physical characterization of retentates and permeates from MF of skim milk at filtration temperatures of 50 and $60^{\circ} \mathrm{C}$ and pore size $0.10 \mu \mathrm{m}$ is presented in Table 5 . The MF of skim milk at $60^{\circ} \mathrm{C}$ gave significantly less $\mathrm{CP}$ and casein in the retentate compared with filtration at $50^{\circ} \mathrm{C}$. Significantly lower concentrations of native whey proteins and calcium permeated the membrane at $60^{\circ} \mathrm{C}$ than at $50^{\circ} \mathrm{C}$. The viscosity of retentates and permeates were lower at $60^{\circ} \mathrm{C}$ than at $50^{\circ} \mathrm{C}$, but the difference in viscosity was only significant for the permeates. Figure 4 shows 
the protein composition of pasteurized skim milk and retentates and permeates from $\mathrm{MF}$ at 50 and $60^{\circ} \mathrm{C}$. The protein composition is adjusted for both TP content in the respective sample and molar extinction coefficient of the specific protein. The capillary electrophoresis analysis did not show any significant differences in the content of $\alpha-\mathrm{LA}, \beta-\mathrm{LG}, \alpha_{\mathrm{S}_{2}} \mathrm{CN}, \alpha_{\mathrm{S}^{-}} \mathrm{CN}, \kappa-\mathrm{CN}$, and $\beta-\mathrm{CN}$ between the retentates from MF at the different temperatures. However, the permeate from $\mathrm{MF}$ at $50^{\circ} \mathrm{C}$ had significantly higher concentrations of $\alpha$-LA and $\beta$-LG than the permeate from $\mathrm{MF}$ at $60^{\circ} \mathrm{C}$. Minor levels of $\alpha_{\mathrm{S}_{1}-} \mathrm{CN}$ and $\beta-\mathrm{CN}$ were detected in the permeates from MF with $0.10 \mu \mathrm{m}$ at both temperatures.

\section{TMP and Protein Transmission During MF}

Figure 5 presents the TMP during MF of pasteurized skim milk both at $50^{\circ} \mathrm{C}$ with different membrane pore sizes $(0.05,0.10$, and $0.20 \mu \mathrm{m})$ and at $60^{\circ} \mathrm{C}$ with membrane pore size of $0.10 \mu \mathrm{m}$. The TMP at time 0 increased with decreasing membrane pore size. When comparing the effect of filtration temperature on TMP development, the initial TMP for $\mathrm{MF}$ at $60^{\circ} \mathrm{C}$ was lower compared with $\mathrm{MF}$ at $50^{\circ} \mathrm{C}$ with the $0.10-\mu \mathrm{m}$ membrane, although with increasing filtration time, the TMP of MF at $60^{\circ} \mathrm{C}$ approached the TMP level of MF at $50^{\circ} \mathrm{C}$. The slopes of the linear curves revealed that $\mathrm{MF}$ at $60^{\circ} \mathrm{C}$ with membrane pore size $0.10 \mu \mathrm{m}$ resulted in the steepest curve, whereas filtration with membrane pore size $0.20 \mu \mathrm{m}$ at $50^{\circ} \mathrm{C}$ only gave a slight increase in TMP with filtration time.

The transmission of proteins during MF of pasteurized skim milk decreased with decreasing pore size (Figure 6). The transmission of proteins through the $0.20 \mu \mathrm{m}$ membrane was quite constant, whereas the transmission of proteins through $0.05-$ and $0.10-\mu \mathrm{m}$ membranes decreased with filtration time. The MF of skim milk with the $0.10-\mu \mathrm{m}$ membrane pore size at $60^{\circ} \mathrm{C}$ gave a larger decline in protein transmission with filtration time compared with $\mathrm{MF}$ at $50^{\circ} \mathrm{C}$.

\section{DISCUSSION}

Choosing an appropriate ceramic membrane pore size is important in an industrial MF process. For instance, for some industrial MF applications it will be of great importance to obtain a permeate purely containing whey proteins with the absence of caseins. This study showed that permeates from MF with 0.05 - and $0.10-\mu \mathrm{m}$ membranes contained whey proteins with negligible amounts of caseins, whereas the permeate from MF with the $0.20-\mu \mathrm{m}$ membrane contained both whey proteins and caseins. These results are in accordance with results presented by Punidadas and Rizvi (1999) who reported that caseins permeated through a membrane with pore size $0.20 \mu \mathrm{m}$, whereas a membrane with pore size $0.05 \mu \mathrm{m}$ was able to retain almost all caseins. However, they used gradient mem-

Table 4. Calculations of protein compositions in skim milk, microfiltration (MF)-retentate and -permeate based on capillary electrophoresis results: relative concentration (\%), protein concentration (\%) as adjusted for true protein content in the sample, and protein concentration (\%) as adjusted for true protein content in the sample and molar extinction coefficient (absorbance) of the protein ${ }^{1}$

\begin{tabular}{|c|c|c|c|c|c|c|c|c|c|}
\hline Item & \multicolumn{3}{|c|}{ Pasteurized skim milk } & \multicolumn{3}{|c|}{ Retentate } & \multicolumn{3}{|c|}{ Permeate } \\
\hline$\overline{\alpha-L A}$ & 3.19 & $0.11^{\mathrm{a}}$ & $0.14^{\mathrm{b}}$ & 1.76 & $0.14^{\mathrm{a}}$ & $0.18^{\mathrm{b}}$ & 27.24 & $0.11^{\mathrm{a}}$ & $0.11^{\mathrm{a}}$ \\
\hline$\beta-\mathrm{LG}$ & 9.17 & $0.32^{\mathrm{a}}$ & $0.42^{\mathrm{b}}$ & 5.71 & $0.44^{\mathrm{a}}$ & $0.60^{\mathrm{b}}$ & 70.11 & $0.27^{\mathrm{a}}$ & $0.28^{\mathrm{a}}$ \\
\hline$\kappa-\mathrm{CN}$ & 6.94 & $0.24^{\mathrm{a}}$ & $0.28^{\mathrm{b}}$ & 7.87 & $0.61^{\mathrm{a}}$ & $0.73^{\mathrm{b}}$ & ND & ND & ND \\
\hline$\beta-\mathrm{CN}$ & 36.80 & $1.28^{\mathrm{a}}$ & $1.18^{\mathrm{b}}$ & 38.26 & $2.98^{\mathrm{a}}$ & $2.80^{\mathrm{b}}$ & 1.58 & $0.006^{\mathrm{a}}$ & $0.004^{\mathrm{b}}$ \\
\hline Sum & 100.00 & 3.47 & 3.47 & 100.00 & 7.78 & 7.78 & 100.00 & 0.39 & 0.39 \\
\hline
\end{tabular}

$\overline{{ }^{a, b} \mathrm{~b}}$ Means of protein concentrations within the same row and same sample type with different superscript letters differ according to paired $t$-test $(P<0.05)$.

${ }^{1}$ Calculations are presented for samples $(\mathrm{n}=3)$ of pasteurized skim milk, retentate, and permeate from MF of pasteurized skim milk at $50^{\circ} \mathrm{C}$ with a $0.10-\mu \mathrm{m}$ membrane.

${ }^{2}$ Relative concentration $=$ peak area divided by total peak area.

${ }^{3}$ Protein adjusted protein concentration = adjustment of relative concentration with true protein content of sample.

${ }^{4}$ Protein and absorbance adjusted protein concentration = adjustment of relative concentration with true protein content of sample and molar extinction coefficient of protein.

${ }^{5}$ Not detected. 
branes and no permeate pump (no UTP). According to Zulewska et al. (2009), a higher casein proportion is expected to permeate gradient membranes compared with ceramic membranes in a UTP system. In the present study, the effect of ceramic membrane pore sizes in a UTP MF system was investigated. The permeation of caseins through the $0.20-\mu \mathrm{m}$ membrane resulted in an opaque whitish permeate with casein distribution $\left(\alpha_{\mathrm{S}^{-}} \mathrm{CN}: \alpha_{\mathrm{S}^{-}} \mathrm{CN}: \kappa-\mathrm{CN}: \beta-\mathrm{CN}\right)$ similar to that of pasteurized skim milk. Due to the permeation of caseins, the protein concentration in the retentate from MF with the $0.20-\mu \mathrm{m}$ membrane did not reach the protein
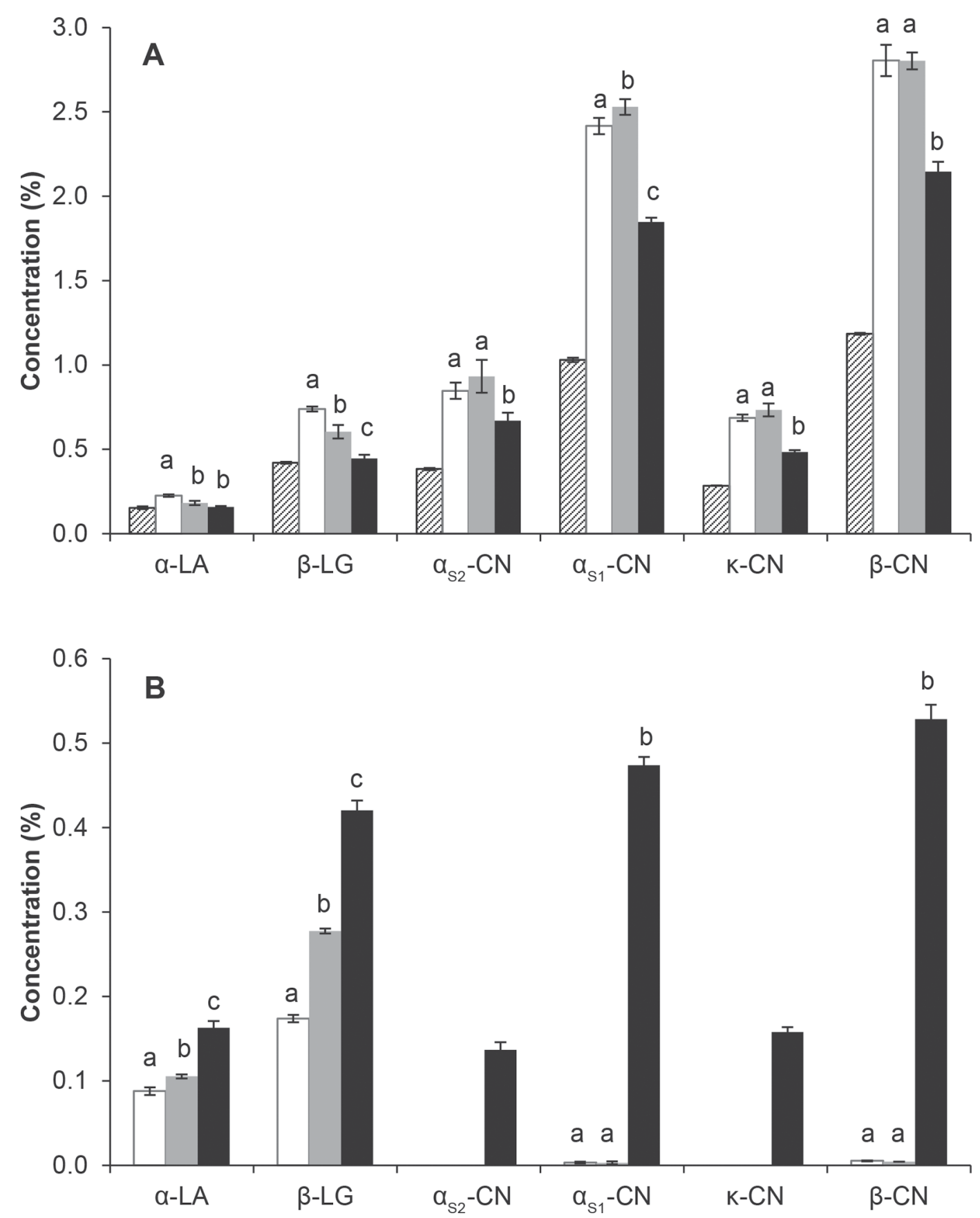

Figure 3. Protein composition (mean $\pm \mathrm{SD}, \mathrm{n}=3$ or 4 ) of $(\mathrm{A})$ pasteurized skim milk (diagonal striped) and retentates, and (B) permeates from microfiltration of pasteurized skim milk at filtration temperature $50^{\circ} \mathrm{C}$ with different pore size membranes: (white) $0.05 \mu \mathrm{m}$, (gray) 0.10 $\mu \mathrm{m}$, and (black) $0.20 \mu \mathrm{m}$. Means within the same protein type with different letters $(\mathrm{a}-\mathrm{c})$ differ according to Tukey's pairwise comparison $(P<$ $0.05)$. Note the different scale values of the y-axes. 
Table 5. Characterization (mean $\pm \mathrm{SD}, \mathrm{n}=3$ or 4 ) of pasteurized skim milk, retentates, and permeates from microfiltration (MF) of pasteurized skim milk with $0.10 \mu \mathrm{m}$ ceramic membrane at 50 and $60^{\circ} \mathrm{C}$

\begin{tabular}{|c|c|c|c|c|c|}
\hline Item & $\begin{array}{l}\text { Pasteurized } \\
\text { skim milk }\end{array}$ & \multicolumn{2}{|c|}{ MF retentates $0.10 \mu \mathrm{m}$} & \multicolumn{2}{|c|}{ MF permeates $0.10 \mu \mathrm{m}$} \\
\hline TS (\%) & $9.25 \pm 0.02$ & $13.25 \pm 0.11^{\mathrm{a}}$ & $13.38 \pm 0.06^{\mathrm{a}}$ & $6.16 \pm 0.14^{\mathrm{a}}$ & $5.82 \pm 0.64^{\mathrm{a}}$ \\
\hline $\mathrm{CP}(\%)$ & $3.65 \pm 0.01$ & $7.96 \pm 0.06^{\mathrm{a}}$ & $7.89 \pm 0.08^{\mathrm{b}}$ & $0.57 \pm 0.04^{\mathrm{a}}$ & $0.50 \pm 0.01^{\mathrm{a}}$ \\
\hline True protein $(\%)$ & $3.47 \pm 0.01$ & $7.78 \pm 0.06^{\mathrm{a}}$ & $7.71 \pm 0.09^{\mathrm{a}}$ & $0.39 \pm 0.02^{\mathrm{a}}$ & $0.33 \pm 0.02^{\mathrm{a}}$ \\
\hline Casein $(\%)$ & $2.91 \pm 0.01$ & $6.92 \pm 0.06^{\mathrm{a}}$ & $6.84 \pm 0.08^{\mathrm{b}}$ & $0.01 \pm 0.00^{\mathrm{a}}$ & $0.01 \pm 0.01^{\mathrm{a}}$ \\
\hline Native whey protein (\%) & $0.54 \pm 0.00$ & $0.86 \pm 0.01^{\mathrm{a}}$ & $0.87 \pm 0.03^{\mathrm{a}}$ & $0.39 \pm 0.01^{\mathrm{a}}$ & $0.32 \pm 0.01^{b}$ \\
\hline Calcium $(\mathrm{g} / \mathrm{kg})$ & $1.20 \pm 0.00$ & $2.33 \pm 0.06^{\mathrm{a}}$ & $2.37 \pm 0.06^{\mathrm{a}}$ & $0.32 \pm 0.01^{\mathrm{a}}$ & $0.29 \pm 0.01^{\mathrm{b}}$ \\
\hline Phosphorus (g/kg) & $1.05 \pm 0.00$ & $1.89 \pm 0.01^{\mathrm{a}}$ & $1.90 \pm 0.02^{\mathrm{a}}$ & $0.44 \pm 0.00^{\mathrm{a}}$ & $0.43 \pm 0.01^{\mathrm{a}}$ \\
\hline Potassium (g/kg) & $1.68 \pm 0.02$ & $1.73 \pm 0.06^{\mathrm{a}}$ & $1.67 \pm 0.06^{\mathrm{a}}$ & $1.63 \pm 0.06^{\mathrm{a}}$ & $1.60 \pm 0.00^{\mathrm{a}}$ \\
\hline Sodium $(\mathrm{g} / \mathrm{kg})$ & $0.38 \pm 0.01$ & $0.40 \pm 0.02^{\mathrm{a}}$ & $0.40 \pm 0.01^{\mathrm{a}}$ & $0.38 \pm 0.00^{\mathrm{a}}$ & $0.39 \pm 0.01^{\mathrm{a}}$ \\
\hline Magnesium (g/kg) & $0.13 \pm 0.00$ & $0.18 \pm 0.01^{\mathrm{a}}$ & $0.17 \pm 0.01^{\mathrm{a}}$ & $0.09 \pm 0.00^{\mathrm{a}}$ & $0.09 \pm 0.00^{\mathrm{a}}$ \\
\hline Copper $(\mathrm{mg} / \mathrm{kg})$ & $0.07 \pm 0.01$ & $0.13 \pm 0.02^{\mathrm{a}}$ & $0.15 \pm 0.04^{\mathrm{a}}$ & $0.01 \pm 0.00^{\mathrm{a}}$ & $0.01 \pm 0.00^{\mathrm{a}}$ \\
\hline $\mathrm{pH}$ & $6.78 \pm 0.00$ & $6.76 \pm 0.06^{\mathrm{a}}$ & $6.77 \pm 0.02^{\mathrm{a}}$ & $6.65 \pm 0.04^{\mathrm{a}}$ & $6.60 \pm 0.04^{\mathrm{a}}$ \\
\hline
\end{tabular}

$\overline{\mathrm{a}, \mathrm{b}}$ Samples with different superscript letters within same sample type differ according to Tukey's pairwise comparison $(P<0.05)$.

concentration of the retentates from MF with 0.05 or $0.10-\mu \mathrm{m}$ membranes at the given volume concentration factor (2.5). On the other hand, Vadi and Rizvi (2001) reported that $0.20-\mu \mathrm{m}$ membranes applied in a UTP MF system retained all caseins. The conflicting results with the present study could be due to differences in mean casein micelle size of the milk microfiltered. Casein micelles are polydisperse, and the diameter of the casein micelles as measured with electron microscopy varies from 50 to $500 \mathrm{~nm}$ (Fox and Kelly, 2004). The mean micelle diameter as measured with dynamic light scattering at $20^{\circ} \mathrm{C}$ has previously been reported to be in the range 149 to $222 \mathrm{~nm}$ for Norwegian Red Cattle (Devold et al., 2000). In the present study of milk from the same breed, the mean casein micelle diameter of the skim milk was $\sim 172 \mathrm{~nm}$. The MF with the $0.20-$ $\mu \mathrm{m}$ membrane divided the milk into a retentate with increased casein micelle size $(\sim 186 \mathrm{~nm})$ and a permeate with smaller casein micelles $(\sim 130 \mathrm{~nm})$. Permeation of caseins through a $0.20-\mu \mathrm{m}$ membrane (ceramic gradient) was also reported by Punidadas and Rizvi (1999). Theoretically, components smaller than $200 \mathrm{~nm}$ are able to permeate a $0.20-\mu \mathrm{m}$ membrane. However, the given pore size of a membrane should be considered to be more an indication than a precise definition of the separating ability of the membrane. Because the casein micelle diameter of the skim milk was $172 \mathrm{~nm}$, casein micelles on the smaller tail of the distribution were expected to permeate the $0.20-\mu \mathrm{m}$ membrane.

The MF of pasteurized skim milk with the 0.05$\mu \mathrm{m}$ membrane gave a significantly higher retention of native whey proteins compared with the $0.10-\mu \mathrm{m}$ membrane. The $\beta$-LG has a molecular weight of approximately $18 \mathrm{kDa}$ in its monomeric form (Léonil et al., 1995). At the $\mathrm{pH}$ of milk ( $\mathrm{pH} 6.7)$ and at a temperature of $50^{\circ} \mathrm{C}$, around $50 \%$ of the $\beta$-LG exist in the dimeric form and has a hydrodynamic radius close to $2.5 \mathrm{~nm}$ (Aymard et al., 1996). Due to the size of $\beta$-LG at the given filtration temperature $\left(50^{\circ} \mathrm{C}\right)$, a similar transmission of $\beta$-LG through the $0.05-$ and $0.10-\mu \mathrm{m}$ pore size membranes was expected. Further investigations are necessary to explain the lower transmission of whey proteins at MF with the 0.05- $\mu \mathrm{m}$ membrane. It can be questioned whether the lower constant flux at MF with membrane pore size of $0.05 \mu \mathrm{m}(44 \mathrm{~L} /$ $\mathrm{m}^{2} \cdot \mathrm{h}$ ) compared with the flux at MF with membrane pore size $0.10 \mu \mathrm{m}\left(59 \mathrm{~L} / \mathrm{m}^{2} \cdot \mathrm{h}\right)$ influenced the protein transmission. However, the approximately same slow and constant increase in TMP with filtration time for both pore sizes indicated that both membranes were run above the critical flux (Howell, 1995; Brans et al., 2004). The increase in TMP during MF with 0.05- and $0.10-\mu \mathrm{m}$ membranes was accompanied with a slow and constant decrease in protein transmission. The reduced transmission of proteins as a consequence of increased membrane resistance due to fouling has previously been reported (Le Berre and Daufin, 1996; Gésan-Guiziou et al., 1999; Gésan-Guiziou et al., 2000; Jimenez-Lopez et al., 2008; Lawrence et al., 2008; Adams et al., 2015b). The TMP and protein transmission measured during MF of skim milk with the $0.20-\mu \mathrm{m}$ membrane were approximately constant, suggesting that the MF operation was run below the critical flux. The flux used during $\mathrm{MF}$ with the $0.20-\mu \mathrm{m}$ membrane could have been 

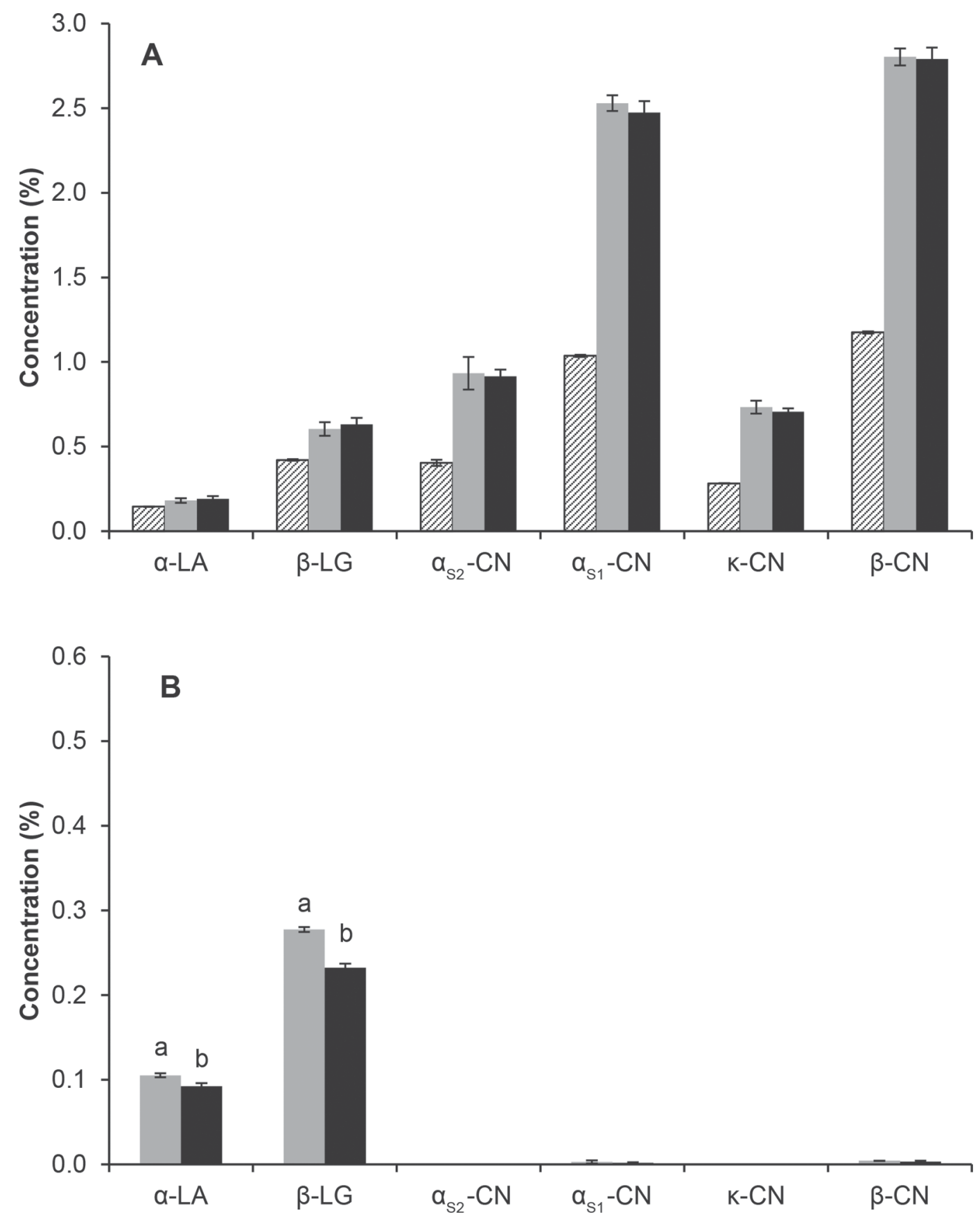

Figure 4. Protein composition (mean $\pm \mathrm{SD}, \mathrm{n}=3$ ) of $(\mathrm{A})$ pasteurized skim milk (diagonal striped) and retentates, and (B) permeates from microfiltration of pasteurized skim milk with a $0.10-\mu \mathrm{m}$ membrane at different filtration temperatures: (gray) $50^{\circ} \mathrm{C}$, and (black) $60^{\circ} \mathrm{C}$. Means within the same protein type with different letters $(\mathrm{a}, \mathrm{b})$ differ according to Tukey's pairwise comparison $(P<0.05)$. Note the different scale values of the y-axes.

increased to ensure operation of MF above the critical flux as for MF with the 0.05- and 0.10- $\mu$ m membranes. From an industrial point of view, the flux should be as high as possible to maximize the utilization of the membrane area. However, fouling is a limiting factor in MF of skim milk, and an MF process with a steeper increase in TMP with filtration time requires more frequent cleaning cycles. Lower constant flux values at MF with the 0.05 - and $0.10-\mu \mathrm{m}$ membranes could give longer processing times. Further work is needed to 


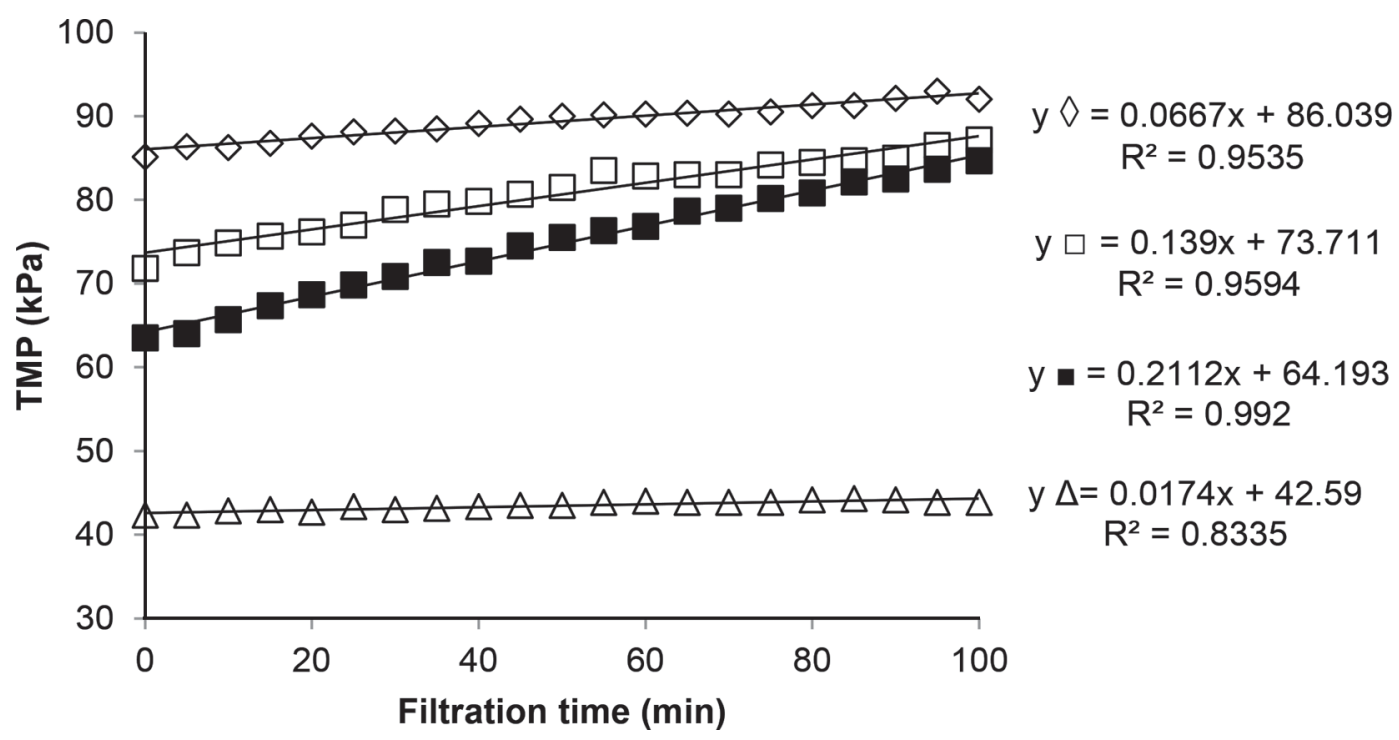

Figure 5. Transmembrane pressure (TMP; mean, $\mathrm{n}=3$ or 4 ) during microfiltration of pasteurized skim milk at $50^{\circ} \mathrm{C}$ with ceramic membranes with pore sizes: $(\diamond) 0.05 \mu \mathrm{m},(\square) 0.10 \mu \mathrm{m}$; and $(\Delta) 0.20 \mu \mathrm{m}$, and at $60^{\circ} \mathrm{C}$ with a ceramic membrane with pore size $(\boldsymbol{\square}) 0.10 \mu \mathrm{m}$. Trends are indicated by linear regression lines. $\mathrm{R}^{2}$-values report how closely the estimated values for the linear regression line correspond to the actual data.

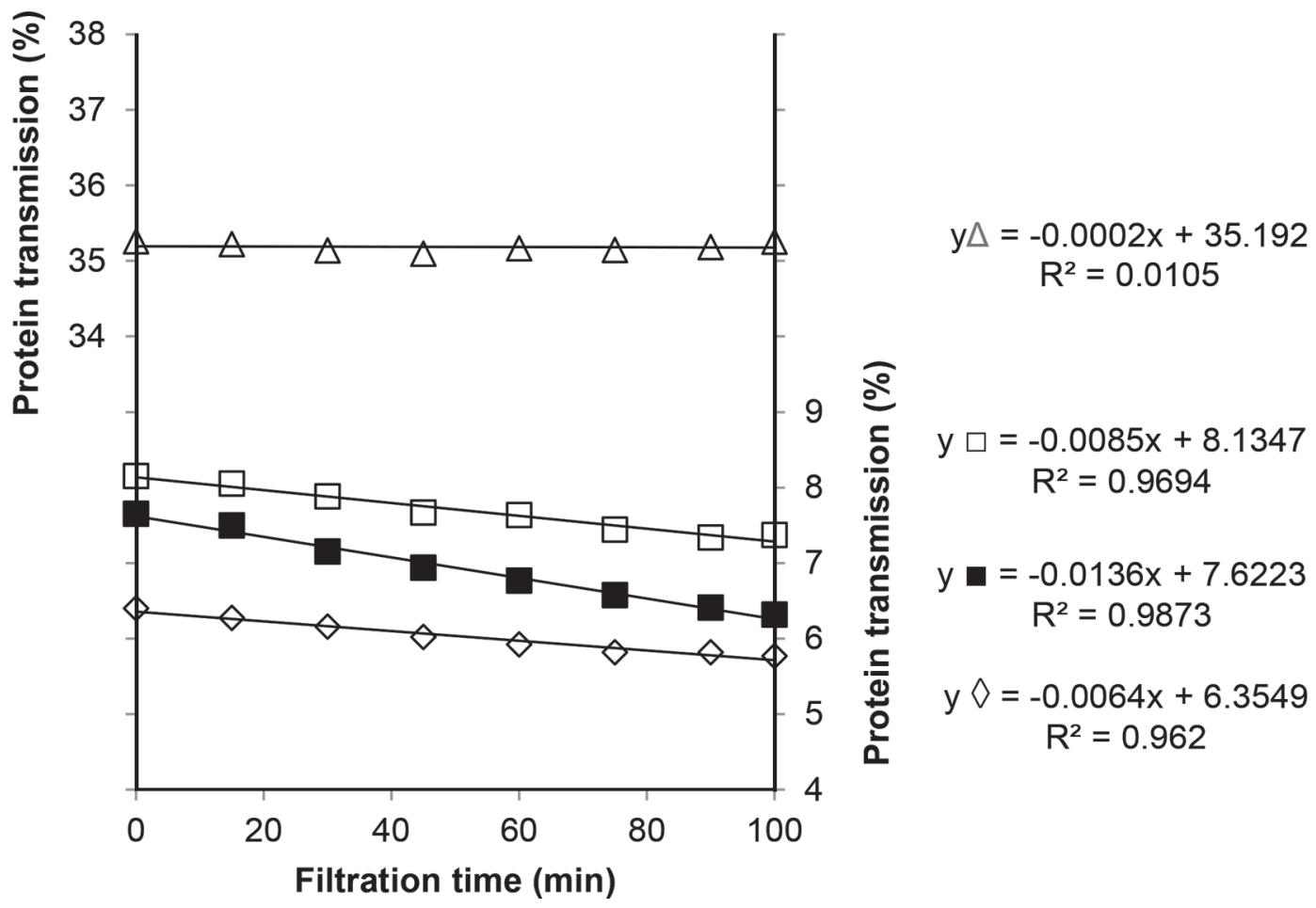

Figure 6. Transmission of proteins (mean, $\mathrm{n}=3$ or 4 ) as measured with MilkoScan (Foss, Hillerød, Denmark) during microfiltration of pasteurized skim milk at $50^{\circ} \mathrm{C}$ with ceramic membranes with pore sizes: $(\diamond) 0.05 \mu \mathrm{m},(\square) 0.10 \mu \mathrm{m}$, and $(\Delta) 0.20 \mu \mathrm{m}$, and at $60^{\circ} \mathrm{C}$ with a ceramic membrane with pore size $(\boldsymbol{\square}) 0.10 \mu \mathrm{m}$. Note the different scale values of the y-axes. Trends are indicated by linear regression lines. $\mathrm{R}^{2}$-values report how closely the estimated values for the linear regression line correspond to the actual data. 
find the optimal stable MF operating conditions with these membranes to achieve stable TMP and protein transmission, and consequently longer operating times.

The retentate from MF of skim milk with the $0.05-\mu \mathrm{m}$ membrane contained significantly higher trace amounts of copper than the retentate from MF with the $0.10-\mu \mathrm{m}$ membrane. This observation could be explained by the increased concentration of $\alpha-\mathrm{LA}$ and $\beta-\mathrm{LG}$ and their ability to chelate copper (Baumy and Brule, 1988). A correlation plot revealed a linear correlation between content of native whey protein and copper in retentates and permeates (correlation plot not shown). As expected, a linear correlation was observed between the content of calcium and phosphorus and the content of casein in retentates and permeates (correlation plot not shown). Concentration of caseins results in a simultaneous concentration of calcium and phosphorus because two-thirds of the calcium and one-half of the phosphate in milk are present in the casein micelles (de la Fuente, 1998; Gaucheron, 2005). The MF of skim milk with the $0.10-\mu \mathrm{m}$ membrane at $60^{\circ} \mathrm{C}$ resulted in a permeate with significantly less native whey proteins and calcium compared with the permeate from $\mathrm{MF}$ at $50^{\circ} \mathrm{C}$. At the same time, a higher content of calcium in the retentate from $\mathrm{MF}$ at $60^{\circ} \mathrm{C}$ than at $50^{\circ} \mathrm{C}$ was observed (not significant), indicating a higher retention of calcium at $60^{\circ} \mathrm{C}$. The increased retention of calcium at higher temperatures could most probably be explained by the reduced solubility of calcium as reported by Pouliot et al. (1988). They observed a reduction in soluble calcium and phosphate of roughly 30 and $25 \%$, respectively, when heating skim milk from 4 to $60^{\circ} \mathrm{C}$ for $60 \mathrm{~min}$.

The significantly lower transmission of native whey proteins (both $\alpha$-LA and $\beta$-LG) with elevated filtration temperature could be due to a certain degree of denaturation. Although the denaturation of $\alpha-\mathrm{LA}$ and $\beta$-LG is reported to take place at temperatures above $70^{\circ} \mathrm{C}$ (Anema, 2009), conformational changes have been reported to begin at lower temperatures (Qi et al., 1995, 1997). However, the content of native whey protein was the same in retentates from MF at both filtration temperatures. If a filtration temperature of $60^{\circ} \mathrm{C}$ was causing denaturation, a difference in native whey protein content between retentates from MF at 50 and $60^{\circ} \mathrm{C}$ would have been expected. Additionally, denatured whey proteins would aggregate and precipitate with casein during Kjeldahl sample preparation, resulting in an increased amount of casein. Thus, if denaturation took place, a lower content of native whey protein and a higher content of casein in the retentate from $\mathrm{MF}$ at $60^{\circ} \mathrm{C}$ than at $50^{\circ} \mathrm{C}$ would have been expected. The results indicate that the lower transmission of native whey proteins with elevated filtration temperature was not solely caused by denaturation. A more likely explanation for the reduced amount of native whey proteins in the permeate from $\mathrm{MF}$ at $60^{\circ} \mathrm{C}$ is the possible interaction of whey proteins with deposited casein micelles on the membrane surface, as proposed by Jimenez-Lopez et al. (2008). The significantly lower concentration of casein observed in the retentate from $\mathrm{MF}$ at $60^{\circ} \mathrm{C}$ than at $50^{\circ} \mathrm{C}$ could be due to fouling. This assumption was supported by the more rapid increase in TMP with filtration time at $60^{\circ} \mathrm{C}$ than at $50^{\circ} \mathrm{C}$. According to Jimenez-Lopez et al. (2008), casein micelles are the most important contributor to the initial deposit build-up during MF of skim milk at $48^{\circ} \mathrm{C}$. They suggested that a high concentration of casein micelles in the deposit could increase the electrostatic interactions between the casein micelles and the soluble protein, thereby causing a decreased soluble protein transmission. Thus, in the present study, the potential higher concentration of caseins deposited on the membrane at $60^{\circ} \mathrm{C}$ than at $50^{\circ} \mathrm{C}$ could be the reason for the higher retention of native whey proteins through increased electrostatic interactions.

Hurt et al. (2015) also reported a decrease in native whey protein transmission when increasing filtration temperature from 50 to $65^{\circ} \mathrm{C}$, but they did not observe a change in the ratio of $\beta$-LG and $\alpha$-LA when SDS-PAGE was used for analysis. However, potential differences in $\beta-\mathrm{LG}$ and $\alpha-\mathrm{LA}$ concentrations may have been present, but may be difficult to unveil if the result is given as relative concentrations or ratios. The new calculation procedure presented in the present study could be used to quantify proteins analyzed with capillary electrophoresis or reversed-phase HPLC. Real values give the possible advantage to observe significant differences that are difficult to detect with relative concentrations or ratios. For instance, the relative concentration of $\beta$-LG in permeates from $\mathrm{MF}$ at 50 and $60^{\circ} \mathrm{C}$ was 70.1 and $69.5 \%$, respectively (results not shown). By conversion of the relative concentrations to real concentration values, a significant difference in the $\beta$-LG content of the permeates was revealed $\left(\right.$ at $50^{\circ} \mathrm{C}, 0.28 \%$; and at $60^{\circ} \mathrm{C}$, $0.23 \%$ ). The protein composition of skim milk after protein and absorbance adjustment was close to the composition of milk as reported by Farrell et al. (2004).

\section{CONCLUSIONS}

Ceramic membrane pore size and filtration temperature significantly influenced the protein composition of retentates and permeates when skim milk was microfiltered in a UTP system to a volume concentration factor of 2.5. The $0.10-\mu \mathrm{m}$ membrane was the most suitable membrane for protein fractionation of skim milk into a casein-rich retentate and a permeate with native whey proteins. A higher amount of native whey proteins 
permeated the $0.20-\mu \mathrm{m}$ membrane than the 0.05 - and $0.10-\mu \mathrm{m}$ membranes $(0.50,0.24$, and $0.39 \%$, respectively), but also significant amounts of smaller casein micelles permeated this membrane $(1.4 \%)$. A permeate free from casein can be beneficial in the production of native whey protein concentrates and in applications where transparency is an important functional characteristic. Increasing temperature of MF from 50 to $60^{\circ} \mathrm{C}$ when using the $0.10-\mu \mathrm{m}$ ceramic membrane caused a reduction in native whey protein permeation and a steeper TMP increase during filtration, probably caused by interaction of whey proteins with deposited casein micelles on the membrane surface. Further work is needed to find the optimal flux for longer MF processing times with $0.10-\mu \mathrm{m}$ membrane at $50^{\circ} \mathrm{C}$.

\section{ACKNOWLEDGMENTS}

This research work was financially supported by TINE SA (Oslo, Norway) and the Research Council of Norway (Oslo, Norway) via the industrial PhD scheme. The authors acknowledge Geirfinn Lund and Ola Tjåland (NMBU, Ås, Norway) for assisting practical work in the pilot plant, and the staff at the laboratory at IKBM (NMBU) for analytical work. Special thanks go to Ahmed Abdelghani (NMBU) for his help in persistently developing the capillary electrophoresis analysis and for valuable discussions. The authors also thank Tom Hoffmann (Hoffmann Milktreatment, Hølen, Norway) for developing the pilot-scale MF, teaching how to operate it, and useful discussions around filtration. Membranteknikk AS (Flekkefjord, Norway) is acknowledged for supplying membranes.

\section{REFERENCES}

Adams, M. C., E. E. Hurt, and D. M. Barbano. 2015a. Effect of ceramic membrane channel geometry and uniform transmembrane pressure on limiting flux and serum protein removal during skim milk microfiltration. J. Dairy Sci. 98:7527-7543.

Adams, M. C., E. E. Hurt, and D. M. Barbano. 2015b. Effect of soluble calcium and lactose on limiting flux and serum protein removal during skim milk microfiltration. J. Dairy Sci. 98:7483-7497.

Anema, S. G. 2009. The whey proteins in milk: Thermal denaturation, physical interactions and effects on the functional properties in milk. Pages 239-281 in Milk Proteins: From Expression to Food. A. Thompson, M. Boland, and H. Singh, ed. Academic Press, London, UK.

Aymard, P., D. Durand, and T. Nicolai. 1996. The effect of temperature and ionic strength on the dimerisation of $\beta$-lactoglobulin. Int. J. Biol. Macromol. 19:213-221.

Baumy, J. J., and G. Brule. 1988. Binding of bivalent cations to $\alpha$-lactalbumin and $\beta$-lactoglobulin: Effect of $\mathrm{pH}$ and ionic strength. Lait 68:33-48.

Brandsma, R. L., and S. S. H. Rizvi. 1999. Depletion of whey proteins and calcium by microfiltration of acidified skim milk prior to cheese making. J. Dairy Sci. 82:2063-2069.

Brans, G., C. G. P. H. Schroën, R. G. M. van der Sman, and R. M. Boom. 2004. Membrane fractionation of milk: State of the art and challenges. J. Membr. Sci. 243:263-272. de la Fuente, M. A. 1998. Changes in the mineral balance of milk submitted to technological treatments. Trends Food Sci. Technol. 9:281-288.

Devold, T. G., M. J. Brovold, T. Langsrud, and G. E. Vegarud. 2000. Size of native and heated casein micelles, content of protein and minerals in milk from Norwegian Red Cattle-Effect of milk protein polymorphism and different feeding regimes. Int. Dairy J. 10:313-323.

Dupont, D., T. Croguennec, A. Brodkorb, and R. Kouaouci. 2013. Quantification of proteins in milk and milk products. Pages 87-134 in Advanced Dairy Chemistry. Volume 1A: Proteins: Basic Aspects. P. L. H. McSweeney and P. F. Fox, ed. Springer Science+Business Media LLC, New York, NY.

Farrell, H. M. Jr., R. Jimenez-Flores, G. T. Bleck, E. M. Brown, J. E. Butler, L. K. Creamer, C. L. Hicks, C. M. Hollar, K. F. Ng-KwaiHang, and H. E. Swaisgood. 2004. Nomenclature of the proteins of cows' milk-Sixth revision. J. Dairy Sci. 87:1641-1674.

Fox, P. F., and A. L. Kelly. 2004. The caseins. Pages 29-71 in Protein in Food Processing. R. Yada, ed. Woodhead Publishing Limited, Cambridge, UK.

Gaucheron, F. 2005. The minerals of milk. Reprod. Nutr. Dev. 45:473483.

Gésan-Guiziou, G., E. Boyaval, and G. Daufin. 1999. Critical stability conditions in crossflow microfiltration of skimmed milk: Transition to irreversible deposition. J. Membr. Sci. 158:211-222.

Gésan-Guiziou, G., G. Daufin, and E. Boyaval. 2000. Critical stability conditions in skimmed milk crossflow microfiltration: Impact on operating modes. Lait 80:129-140.

Heck, J. M. L., C. Olieman, A. Schennink, H. J. F. van Valenberg, M. H. P. W. Visker, R. C. R. Meuldijk, and A. C. M. van Hooijdonk. 2008. Estimation of variation in concentration, phosphorylation and genetic polymorphism of milk proteins using capillary zone electrophoresis. Int. Dairy J. 18:548-555.

Hernández, A., and F. M. Harte. 2009. Isolation of caseins from whey proteins by microfiltration modifying the mineral balance in skim milk. J. Dairy Sci. 92:5357-5362.

Hoffmann, T., inventor. 2011. Membrane filtration and membrane filtration assembly. TINE SA, assignee. US Pat. No. 13/635,335 (NO Pat. No. 330,181).

Howell, J. A. 1995. Sub-critical flux operation of microfiltration. J. Membr. Sci. 107:165-171.

Hurt, E. E., M. C. Adams, and D. M. Barbano. 2015. Microfiltration of skim milk and modified skim milk using a $0.1-\mu \mathrm{m}$ ceramic uniform transmembrane pressure system at temperatures of 50,55 , 60 , and $65^{\circ}$ C. J. Dairy Sci. 98:765-780.

IDF. 2001. Milk-Determination of nitrogen content-Part 4: Determination of non-protein-nitrogen content. 20-4:2001. International Dairy Federation, Brussels, Belgium.

IDF. 2004. Milk-Determination of casein-nitrogen content-Part 1: Indirect method (Reference method). 29-1:2004. International Dairy Federation, Brussels, Belgium.

IDF. 2010a. Milk, cream and evaporated milk-Determination of total solids content (Reference method). 21:2010. International Dairy Federation, Brussels, Belgium.

IDF. 2010b. Milk-Determination of fat content-Gravimetric method (Reference method). 1:2010. International Dairy Federation, Brussels, Belgium.

IDF. 2014. Milk and milk products-Determination of nitrogen content-Part 1: Kjeldahl principle and crude protein calculation. 201:2014. International Dairy Federation, Brussels, Belgium.

Jenness, R., and J. Koops. 1962. Preparation and properties of a salt solution which simulates milk ultrafiltrate. Neth. Milk Dairy J. $16: 153-164$

Jimenez-Lopez, A. J. E., N. Leconte, O. Dehainault, C. Geneste, L. Fromont, and G. Gésan-Guiziou. 2008. Role of milk constituents on critical conditions and deposit structure in skimmilk microfiltration $(0.1 \mu \mathrm{m})$. Separ. Purif. Tech. 61:33-43.

Jørgensen, C. E., R. K. Abrahamsen, E.-O. Rukke, A.-G. Johansen R. B. Schüller, and S. B. Skeie. 2015. Improving the structure and rheology of high protein, low fat yoghurt with undenatured whey proteins. Int. Dairy J. 47:6-18. 
Kersten, M. 2001. Proteinfraktionierung mittels Membrantrennverfahren. PhD Thesis. Department of Life Science Engineering, Technical University of Munich, Munich, Germany.

Kuipers, B. J. H., and H. Gruppen. 2007. Prediction of molar extinction coefficients of proteins and peptides using UV absorption of the constituent amino acids at $214 \mathrm{~nm}$ to enable quantitative reverse phase high-performance liquid chromatography-mass spectrometry analysis. J. Agric. Food Chem. 55:5445-5451.

Lawrence, N. D., S. E. Kentish, A. J. O'Connor, A. R. Barber, and G. W. Stevens. 2008. Microfiltration of skim milk using polymeric membranes for casein concentrate manufacture. Separ. Purif. Tech. 60:237-244.

Le Berre, O., and G. Daufin. 1996. Skimmilk crossflow microfiltration performance versus permeation flux to wall shear stress ratio. J. Membr. Sci. 117:261-270.

Léonil, J., D. Mollé, F. Gaucheron, P. Arpino, P. Guénot, and J. L. Maubois. 1995. Analysis of major bovine milk proteins by on-line high-performance liquid chromatography and electrospray ionization-mass spectrometry. Lait 75:193-210.

Liu, D. Z., M. G. Weeks, D. E. Dunstan, and G. J. O. Martin. 2013. Temperature-dependent dynamics of bovine casein micelles in the range $10-40{ }^{\circ} \mathrm{C}$. Food Chem. 141:4081-4086.

Maubois, J.-L. 2002. Membrane microfiltration: a tool for a new approach in dairy technology. Aust. J. Dairy Technol. 57:92-96.

Miralles, B., M. Ramos, and L. Amigo. 2003. Influence of proteolysis of milk on the whey protein to total protein ratio as determined by capillary electrophoresis. J. Dairy Sci. 86:2813-2817.

Moe, K. M., D. Porcellato, and S. Skeie. 2013. Metabolism of milk fat globule membrane components by nonstarter lactic acid bacteria isolated from cheese. J. Dairy Sci. 96:727-739.

Morin, P., R. Jiménez-Flores, and Y. Pouliot. 2004. Effect of temperature and pore size on the fractionation of fresh and reconstituted buttermilk by microfiltration. J. Dairy Sci. 87:267-273.

Pouliot, Y., M. Boulet, and P. Paquin. 1988. Observations on the heat-induced salt balance changes in milk. I. Effect of heating time between 4 and $90{ }^{\circ} \mathrm{C}$. J. Dairy Res. 56:185-192.

Punidadas, P., and S. S. H. Rizvi. 1999. Separation of milk proteins into fractions rich in casein or whey proteins by cross flow filtration. Food Res. Int. 31:265-272.
Qi, X. L., S. Brownlow, C. Holt, and P. Sellers. 1995. Thermal denaturation of $\beta$-lactoglobulin: effect of protein concentration at $\mathrm{pH} 6.75$ and 8.05. Biochim. Biophys. Acta 1248:43-49.

Qi, X. L., C. Holt, D. McNulty, D. T. Clarke, S. Brownlow, and G. R. Jones. 1997. Effect of temperature on the secondary structure of $\beta$-lactoglobulin at $\mathrm{pH} 6.7$, as determined by $\mathrm{CD}$ and IR spectroscopy: a test of the molten globule hypothesis. Biochem. J. 324:341-346.

Recio, I., M.-L. Pérez-Rodríguez, M. Ramos, and L. Amigo. 1997. Capillary electrophoretic analysis of genetic variants of milk proteins from different species. J. Chromatogr. A 768:47-56.

Rose, D. 1968. Relation between micellar and serum casein in bovine milk. J. Dairy Sci. 51:1897-1902.

Schmitt, M., F. Saulnier, L. Malhautier, and G. Linden. 1993. Effect of temperature on the salt balance of milk studied by capillary ion electrophoresis. J. Chromatogr. A 640:419-424.

Schüller, R. B., M. Tande, and L. Amundsen. 2010. Experimental determination of time dependent yield properties. Annual Transactions of the Nordic Rheology Society 18:25-29.

Seibel, J. R., M. S. Molitor, and J. A. Lucey. 2015. Properties of casein concentrates containing various levels of beta-casein. Int. J. Dairy Technol. 68:24-29.

Svanborg, S., A.-G. Johansen, R. K. Abrahamsen, and S. B. Skeie. 2014. Initial pasteurisation effects on the protein fractionation of skimmed milk by microfiltration. Int. Dairy J. 37:26-30.

Vadi, P. K., and S. S. H. Rizvi. 2001. Experimental evaluation of a uniform transmembrane pressure crossflow microfiltration unit for the concentration of micellar casein from skim milk. J. Membr. Sci. 189:69-82.

Van Hekken, D. L., and V. H. Holsinger. 2000. Use of cold microfiltration to produce unique $\beta$-casein enriched milk gels. Lait 80:69-76.

Walstra, P., J. T. M. Wouters, and T. J. Geurts. 2006. Dairy Science and Technology. 2nd ed. Taylor and Francis Group, LLC, Boca Raton, FL.

Zulewska, J., M. Newbold, and D. M. Barbano. 2009. Efficiency of serum protein removal from skim milk with ceramic and polymeric membranes at $50^{\circ}$ C. J. Dairy Sci. 92:1361-1377. 